under such circumstances; certain it is that prolonged pressure, such as is occasionally exercised on the vessels behind the uterus, and even on those in the substance of the uterus itself, by the powerful expulsive efforts of this organ, particularly when the liquor amnii has been evacuated, must have a very considerable effect in retarding the circulation in the neighbouring vessels. That the result may be actual coagulation in the vessels subjected to the pressure, and perhaps even injured by it, it is not difficult to conceive.

The more important of the causes now under discussion have yet to be mentioned.

$$
\text { (To be continued.) }
$$

\section{NOTE ON NEST-CELLS,* IN RELATION TO EPITHELIAL CANCER.}

\section{By ANDREW CLARK, M.D., \&C.}

Althougr nest cells have been found in sebaeeous cysts and myeloid tumours, an opinion still generally prevails, that the presence of these cells in any new growth is almost or quite characteristic of epithelial cancer.

As there are in my pathological collection about twenty specimens which prove that this opinion must be modified or abandoned, and as there has recently prevailed in the eastern part of the metropolis a peculiar affection of the mucous membrane of the tongue in which nest-cells are found in considerable numbers, I have thought it desirable to make a short note upon the subject.

1. I have occasionally found nest-cells in the diseased secretions of mucous membranes, particularly in those of the mouth, pharynx, tonsils, and cesophagus.

2. In apparently healthy mucous membranes, furnished with several layers of epithelial cells, papillw, and large follicles, nest-cells may commonly be found on some part of the surface: I have scarcely ever found them absent in new growths occupying the same localities.

3. I have found nest-cells in common warty tumours of the skin, in cutaneous cysts, in chronic enlargement of the tonsils and prostate, in cholesteatomatous and myeloid tumours, in small tumours of the choroid plexus, in polypi, in the thick white integument round old ulcers, and in the various regions associated with other growths.

4. In a kind of diphtheritic affection of the tongue recently and still to a limited extent prevailing in the east end of London, and in the London Hospitals, I have found nest-cells in considerable numbers. This affectiont becomes first apparent in the form of white cloudy patches irregularly scattered over the tongue. These grow opaque, thick, and soft, and are removed, leaving a bright-red shallow erosion with very thick white elevated margins. A portion of the white patch just before its discharge, or a little of the thickened margin carefully transferred to the field of the microscope, with as little manipulation and compression as possible, will usually exhibit nest-cells analogous to those present in epithelial cancer.

5. It would be out of place at present, and in the pages of a practical journal, to discuss the mode of origin of these nestcells : but I think it worthy of observation that they are found in intimate connexion with follicles and papillæ; ; and that sections of both, when hypertrophied, are frequently mistaken for the calls themselves.

It appears probable, from these facts, that the presence of nest-cells, even in considerable numbers, cannot be considered characteristic of epithelial cancer. As, moreover, the common epithelial cells in the advanced stage of the diphtheritic deposit above described, exhibit changes in their form and in their nuclei closely analogous to those observed in epithelial cancer, it is obvions that we must seek in wider conditions than those of structure only for a true definition of this growth.

Montague-place, Russell-square, January, 1858.

* Synon. ; Laminated epithelial capsules, epidermic globes, compound epithelial cells, \&c., \&c.

+ Here described only in relation to the "nest-cells ;" but the author hopes to be able to give a complete accuunt of it shortly in these pages.

† Th is is not intended to invalidate the explanation of Rokitansby; for nest-cells are produced where neither follieles nor papillwe exist, though in f ewer numbers.

34

\section{SULPHURIC ACID AND SULPHATE OF ZINC AS A CAUSTIC AGENT.}

BY HENRY THOMPSON, F.R.C.S., M.B. Lond., ASSISTANT-SURGBON TO UNTYERSITY COLLEGE HOSPITAL, ETC.

There is an important chemical principle involved in the application of that potent and manageable caustic, sulphuric acid, which it seems desirable not to lose sight of in applying it for the destruction of living tissues. It consists in this, that the acid mainly acts upon organised matters, whether vegetable or animal, by its powerful tendency to combine with the elements of water contained in them, so that the carbon is left free, forming the black charcoal-like mass with which we are familiar as the result of its action upon all such tissues. Now, the more concentrated is the acid, in its liquid form, the greater is its power to decompose animal or vegetable tissues by abstracting the elements of water. It is desirable, therefore, in adding material to the acid for the purpose of giving it the form of paste, that the substance employed should not be an organised matter capable of furnishing water to the acid, and so weakening its caustic power. Hence the objection to saffron, the material first suggested by Velpeau. On adding the acid to saffron or to any other vegetable tissues, these become immediately carbonised, and the acid is weakened, pro tanto, by its combination with the water of the tissue. Nearly two years ago I observed this effect, and it occurred to me that we might economise the power of the acid by employing carbon in some simple form-common pulverised charcoal, for exampleas the material with which to make the acid into a manageable form for use. Accordingly, so long ago as the summer of 1856 , Mr. Squire of Duke-street made this paste for me, and I employed it successfully, with considerable advantage, for limited surfaces requiring a powerful caustic. Nearly a year ago, Ricord of Paris published this same combination as the best form of caustic for the treatment of ehancre, stating it to be superior to nitric acid or the Vienna paste, which latter he had previously. used. (See a quotation from a clinical lecture delivered by him last winter.)*

In this case the thickening material of the paste at least does not impair the caustic power of the acid, but it appeared desirable to find, if possible, a material for thickening which should not be merely inert, but which should bring with it fresh caustic power, so as to produce a combination possessing the greatest possible destructive force. This suggested itself to me in the form of the dried sulpbate of zinc, in powder, itself a caustic of considerable strength, and well known to have been employed by Professor Simpson, especially for the destruction of some growths from the uterus. By mixing this with strong sulphuric acid, a paste of sufficient consistency is produced, and one that is endowed with exceeding power as a caustic. I employed it first in July last, in the case of an epithelial growth springing from the outer canthus and neighbouring temple of a woman aged seventy, in the Marylebone Infirmary. I deened it unadvisable to remove this tumour, which was the size of a walnut, by the knife, because it was very broad, and because it encroached upon the upper eyelid especially. After six applications, some of them slight and involving only small portions of the tumour, it entirely disappeared, and had cicatrised soundly in September. At no time was there any hæmorrhage whatever. I exhibited the woman at the Medical Society of London in October, a report of which appears in this Journal of Nov. 14th. The patient was asked on that occasion, by some of the fellows present, on which side the tumour had existed, so complete had been the removal and so slight was the resulting scar. I may add that she remains perfectly well at the present moment.

One advantage of this combination consists in the ease with which it is prepared, and in the fact that its constituents may be found in any chemist's shop or surgery. The ordinary sulphate of zinc is to be dried in an oven or sand-bath, so that the water of crystallization is driven off, and a whitish powder remains. Enough of this is to be added to some strong sulphuric acid, in

* "J'ai suecessivement expérimenté la pâte de Vienne, la potasse, l'acid nitrique, le fer rouge, \&c. Tous ces caustiques ont des inconvénients qu'il serait superflu de vous signaler, d'autant que j'ai à vous proposer un agent nouveau d'une merveilleuse efficacité, et à l'abri de tout reproche. Ce caustique, c'est l'acide sulfurique, uni à la poudre de charbon végétal, dans les proportions nécessaires pour former une pâte demisolide," \&c.- "Leçons sur la Chancre," par Dr. Ricord, L'Union Médicale, Jan. 20, 1857. 
order to make a semi-fluid mass of consistence sufficient to prevent its running beyond the spot on which it is placed. The mixture should be kept in a stoppered bottle, and be applied with a small glass spatula or rod. Before using it, the surrounding parts should be protected by a thick layer of cerate or firm ointment, so as to form an embankment limiting the surface to be destroyed, and a layer of the caustic may be made upon this of about the eighth or tenth of an inch in thickness. This is allowed to remain. As in the case of other caustics, I believe, the pain is less in the superficial than in the deeper diseased tissues. In the case mentioned, but little suffering followed the first application, but in subsequent dressings, as deeper and more highly organized tissues were reached, the suffering was severe. Incisions were made through the first slough to admit of the access of the caustic to these parts. There appears to be reason to believe that the amount of pain caused by all caustic applications is less the result of any specific property of the caustic itself, than of the degree of sensibility existing in the part or structures attacked. Other things being equal, there is little doubt that the more powerful and rapid is the action of the caustic, the less is the pain inflicted. On this account also, as well as on other grounds named, the paste in question has appeared to me to deserve the attention of the profession, for use in those instances in which its employ. ment is to be regarded, as in the case cited, a better method of procedure than ablation by the knife.

Wimpole-street, Cavendish-square, Jan. 1858 .

ON A CASE OF

\section{ANEURISM OF THE INNOMINATA ARTERY TREATED BY PRESSURE ON THE CARO- TID AND SUBCLAVIAN TRUNKS.}

By A. M. EDWARDS, F.R.C.S.E.,

JRMOXSTRATOB OF ANATOMY IN THE UNIVERSITY OF EDINBURGH.

SURGERY can do so little towards relieving the disturbed symptoms produced by anenrisms at the root of the neck, that any contribution to our knowledge on the subject must have some value; but I am induced to lay the following case before the profession, not so much on account of any merit specially pertaining to itself, as that it may set other men thinking, and may lead them to some more efficient means of alleviating the sufferings of those who are the victims of deep-seated aneurisms :-

In September, 1856, Mrs. L-, aged fifty, was recommended to my care by Professor Simpson. She was a sallowcomplexioned woman, with hanging, flabhy cheeks; her lips, which were always apart, were livid and drawn down at the angles, and she breathed rapidly. Her countenance presented the peculiar anxious expression of one suffering from a fatal disease. On examining her neck, I found on the right side above the sterno-clivicular articulation a tumour, the size of an apple, situated between the sterno-mastoid mnscle and the middle line of the neck, which pulsated violently, was soft and compressible, giving to the fingers much the same feeling as a vulcanized india-rubber ball, which, though easily compressible, expands again immediately the pressure is withdrawn; and with the expansion of this tumour, fluid seemed rapidly to fill the interior, and to be separated but by a thin partition from the fingers. Another pulsating tumour rose in front of the trachea. They were, though apparently distinct, evidently bulgings out of the same aneurism, as pressure on the one was followed by increase in size of the other. The patient had remarked these tumours about two months before I saw her, and they were, according to her account, increasing rapidly. Any pressure upon them was attended with pain and an increase of cough. She suffered from constant dyspnoea, had entirely given up her ordinary household occupations, and had frequent fainting fits; she rarely ventured even at night to lie down in ber, as, after falling asleep, the laryngeal spasm became so violent, that an attendant had to be on the watch ready to administer restora tives. The ordinary internal remedies were tried, but without much benefit.

As I considered that the aneurism was one of the innominata artery, I thought of placing ligatures on the vessels according to Wardrop's method; but Dr. Laycock, who at my request examined her chest with the stethoscope, considered that the arch of the aorta was also aneurismal, so I gave up the idea of a cutting operation. But it struck me that Mr. Wardrop's principles could be applied to compression, and Mr. Young, of Princes-street, constructed for me an instrument which I shall endeavour to describe:-

A broad leathern belt to go round the chest, and fasten in front with three straps and buckles. On its left posterior and right anterior upper margins are brass buttons. In the middle of its posterior aspect is an iron plate perforated with several holes to admit screws, which attach to it an upright steel rod about eighteen inches long. This rod supports an arc of steel, which is attached to it by a screw allowing a certain amount of motion. In front, this arc is perforated by another screw, about an inch long, with a small cross handle; this projects backwards, and bears a conical piece of cork covered with wash-leather. When the instrument is applied, the upright is at the back and right side of the neck, which rests in the are, and, by shifting the lower end of the upright, pressure with the cork can be regulated and efficiently maintained upon the common carotid artery, the conical sliape of the cork enabling one to confine the pressure to the artery. A strap is carried over the right shoulder from the buttons behind to those in front; on it slides another cone of cork, which can be adjusted over the subclavian. It will be seen that in principle this instrument resembles Bourgery's tourniquet for subclavian pressure.

Mrs. L_ had worn this instrument for several hours of two days, when I was alarmed by observing that the tumour had visibly increased in size. Its walls felt thinner, and the contents were distinctly fluid. The bruit de soufflet was very loud, and the pulsation violent. The treatment, however, was continued, and the pads adjusted so as to stop all pulsation in the branches of the external carotid and in the right wrist. On the fourth day, the tumour, though larger than when the instrument was first applied, was much harder and less compressible. The tracheal portion still, howerer, pulsated violently. Every morning, for the first two weeks, I adjusted the apparatus, at the same time manipulating the tumour rather roughly, with the view of breaking up the fibrine in the sac. But she soon learnt how to apply it for herself, and finding decided benefit from it, bore the treatment cheerfully. She said it was irksome, but never complained of pain.

After the first week, the laryngeal symptoms entirely disappeared and did not return, and she had no more fainting fits; but she complained of some impediment in swallowing, as if some hard body stopped the food in its passage down the gullet. I now feared that the apparent improvement was de. ceptive, and that the tumour was increasing towards the œsophagus; but as this symptom disappeared with the gradual decrease in the bulk of that part of the aneurism which we could judge of by external examination, I now conclude that it arose from the solidification of the contents of the sac in close apposition to the gullet.

By the end of three months, she was well enongh to lay asido the instrument and resume her former household duties. She repeatedly walked a distance of three miles and back to my house, and passed tranquil nights. The external part of the tumour was then and is now the size of a nut, and hard; the tracheal portion has entirely disappeared; the aortic aneurism seems to have made but little progress, and, with the exception of attacks of neuralgia in the face and head and a chronic cough which troubles her every winter, she has been in good health since. She gave up the instrument more than ten months ago. Before she began to use it, a surgenon of great experience told me he expected the external tumour would burst in a day or two, and Dr. Laycock was of the same opinion. Of course, I cannot hope to avert the fatal termination we must always expect in thoracic aneurisms; but I am convinced, and so is the patient, that the compression of the ressels beyond the aneurism was attended with marked benefit, and was the direct cause of its hardening and subsequent rapid decrease in its size.

As far as I am aware, this mode of treatment has not been tried on any previous occasion.

India-strcet, Dec. 1857.

\section{ON A CASE OF FRACTURE OF THE CRANIUM,} WITH PROTRUSION OF BRAIN.

\section{By JOHN ROSE, A.M., M.D., Surgeon R.N.}

A. B—, a boy aged fifteen, fell from the main deck to the lower deck of H.M.S. _ a distance of seven feet, his head coming in contact with a small staple in the deck. He was 